\title{
DR. AND MRS. R. T. GAMMELL OF NORTH DAKOTA RECEIVE CITIZENS AWARD
}

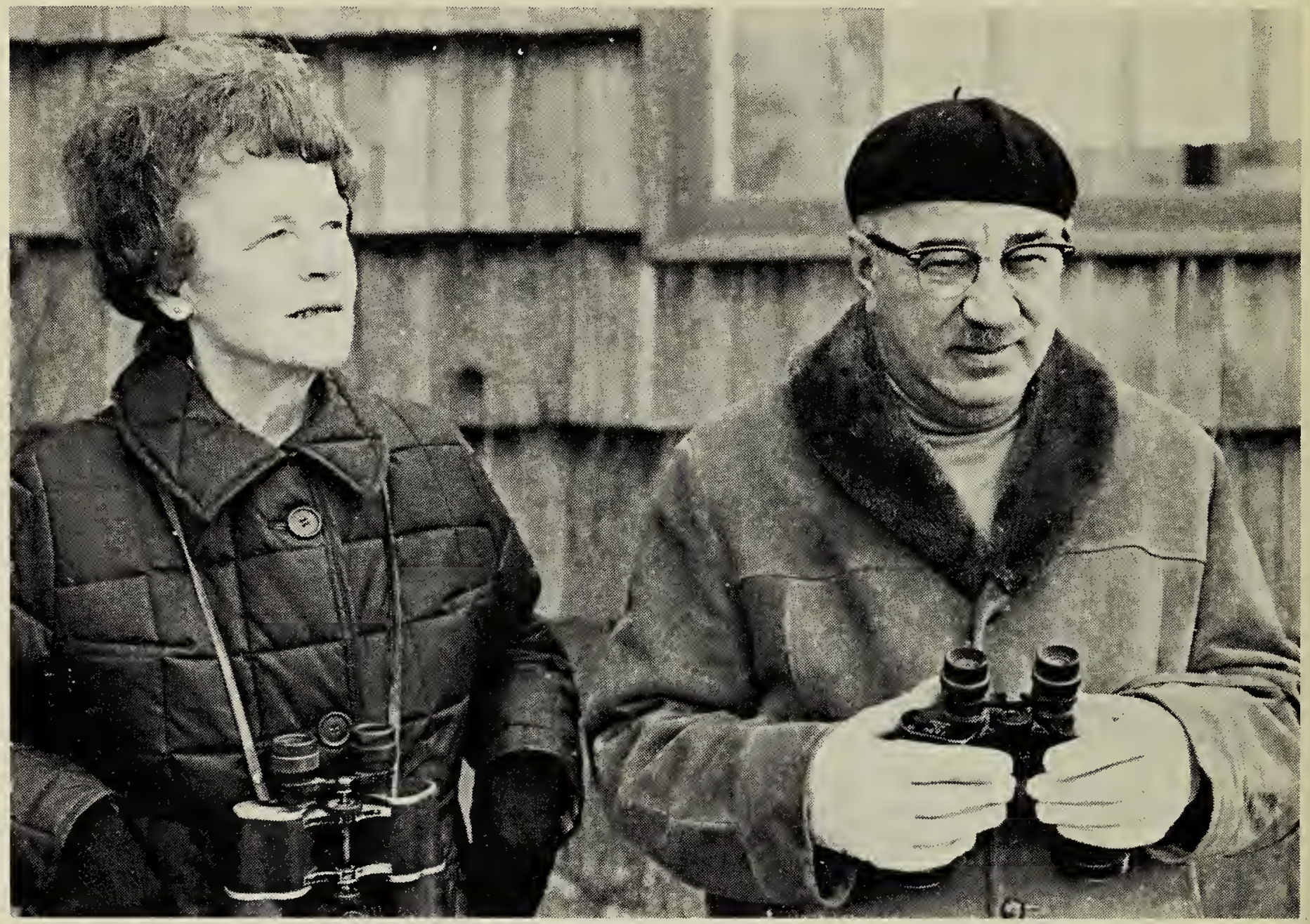

Photo by James E. Frates, Manager, Des Lacs National Wildlife Refuge

The March, 1972 issue of North Dakota Outdoors records the winning of this coveted conservation award by a well-known Kenmare couple, Bob and Ann Gammell.

The Citizens Award is a recently established U.S. Department of the Interior, Bureau of Sport Fisheries and Wildlife, award designed to give special official recognition to private citizens for contributions which they voluntarily make to the public service.

The award was presented in Kenmare, North Dakota, at a special commemorative supper, January 19 , 1972. James E. Frates of the Des Lacs National Wildlife Refuge described the event for North Dakota Outdoors (a monthly publication of the State Game and Fish Department, Bismarck, North Dakota, editor Ed Bry). According to the article the Gammells have, since 1957, banded over 160,000 birds of 224 different species.
Bob and Ann Gammell are always willing to share their interest and knowledge of birds and their home is a favorite stop-over place each summer for birders throughout the United States and Canada. They are enthusiastic supporters of the U.S. National Wildlife Refuge system, particularly the Lostwood and Des Lacs Refuges near Kenmare.

Congratulations from the Blue Jay to the Gammell team.

\section{A. 0. U.}

The American Ornithologists' Union is holding its 90th annual meeting, August $14-18,1972$ at the university in Grand Forks, North Dakota. Several field trips to the wetlands of North Dakota are planned as part of the meeting. The Gammells of Kenmare, N.D. are members of the arrangements committee. 